\title{
KARAKTER MORFOLOGI KOLONI Streptomyces spp. YANG DIISOLASI DARI SUBSTRAT HABITAT CACING NIPAH (Namalycastis rhodochorde) PADA MEDIUM BERBEDA
}

\author{
Tri Rima Setyawati ${ }^{1}$, Rikhsan Kurniatuhadi ${ }^{1}$, Ari Hepi Yanti ${ }^{1}$ \\ ${ }^{1}$ Program Studi Biologi, FMIPA Universitas Tanjungpura, Pontianak
}

Email korespondensi : rikhsan.kurniatuhadi@fmipa.untan.ac.id

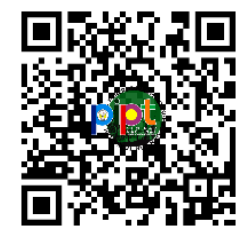

\begin{abstract}
Abstrak
Streptomyces memiliki potensi sebagai sumber metabolit antibakteri yang dapat dikembangkan dan diaplikasikan dalam pengembangan budidaya cacing nipah. Streptomyces memiliki karakter morfologi kultur yang berbeda-beda di beberapa medium agar dan merupakan aspek yang sangat penting dalam proses identifikasi dan klasifikasinya. Streptomyces spp. telah diisolasi dari substrat alami habitat cacing nipah (Namalycastis rhodochorde) di Sungai Kakap Kabupaten Kubu Raya sebanyak enam isolat (NrASA1 - NrASA6) dan telah berhasil dimurnikan untuk dilakukan karakterisasi morfologi koloninya. Penelitian ini bertujuan untuk mengkarakterisasi variasi koloni Streptomyces sehingga diketahui variasi koloni dari genus yang sama pada medium yang berbeda. Karakterisasi dilakukan dengan metode pengamatan langsung terhadap koloni Streptomyces yang dikultur secara kuadran pada medium agar glycerol asparagine (GAA), inorganic salt starch (ISSA), oatmeal (OA), dan starch casein (SCA). Hasil karakterisasi tujuh isolat Streptomyces spp. yang dikultur pada empat medium agar berbeda memperlihatkan bahwa persamaan karakter terlihat dari warna spora matang yang $100 \%$ berwarna coklat, interval diameter koloni antara $3-8 \mathrm{~cm}$, tekstur bersifat cottony. Perbedaan karakter terlihat dari presensi diffusible pigment yang hanya ada pada koloni isolat NrASA1 dan NrASA3 pada medium GAA dan SCA, sedangkan presensi eksudat berwarna coklat tua hanya terjadi pada medium ISSA. Enam isolat Streptomyces diduga memiliki epitet spesies yang berbeda, khususnya antara NrASA1 dan NrASA3 terhadap kode isolat lainnya.
\end{abstract}

10.26418/pipt.2021.29

Kata kunci: Streptomyces, cacing nipah, aktinobakteri, dan Namalycastis rhodochorde.

\section{PENDAHULUAN}

Streptomyces spp. merupakan genera dari kelompok Actinobacteria gram positif yang bersifat kosmopolitan. Streptomyces merupakan kelompok dari Actinobacteria yang dapat diisolasi dari beberapa jenis tanah dan dianggap sebagai bakteri dekomposer aktif pada substrat dengan sumber karbon yang relatif tinggi (Hamid et al., 2020). Komposisi Streptomyces diketahui memiliki proporsi $40 \%$ dari populasi bakteri yang ada di tanah atau substrat lainnya dan menempati proporsi $50 \%$ dari genus Actinobacteria dari genus lainnya (Yepez-Garcia et al., 2020; Abraham dan Chauhan, 2018). Genus ini memiliki sifat adaptif, termasuk pada substrat-subtrat yang bersifat basah, lembab, dan kering yang kaya akan serat organik dari tumbuhan (Ekowati dan Achmad, 2007).

Penelitian Yanti et al., (2020) berhasil mengisolasi tujuh isolat Streptomyces spp. dari substrat habitat cacing nipah (Namalycastis rhodochode) yang bersifat basah dan tergenang serta didominasi oleh serasah tanaman nipah (Nypa fruticans). Streptomyces menjadi bakteri golongan Actinobacteria kunci dalam proses degradasi serasah nipah dan diduga membantu dalam membangun sistem kekebalan bagi cacing nipah di habitatnya. Hal ini dikarenakan Streptomyces yang mampu bersifat antibiosis terhadap mikrob patogen yang ada di lingkungan sekitar substrat (Sivalingam et al., 2019). Beberapa peneliti telah mengisolasi Streptomyces dari substrat tanah, rizosfer tanaman perkebunan, dan substrat mangrove (Fardiyanti et al., 2021; Law et al., 2019; Akbar et al., 2017; Muzaimah et al. 2017: Kawuri, 2016). Potensi Streptomyces sebagai antimikrob dapat dilakukan setelah dilakukan karakterisasi sifat baik morfologi, fisiologi maupun molekuler. Hal ini diperlukan sebagai penunjang dalam 
pengembangan Streptomyces sebagai spesies yang berpotensi menghasilkan metabolit sekunder potensial.

Pelaksanaan karakterisasi fenotip dilakukan dengan melihat variasi karakter dari morfologi koloni bakteri. Hal ini dikarenakan variasi koloni pada genus Streptomyces lebih besar dan cenderung berbeda pada medium yang berbeda komposisi kimianya. Karakterisasi morfologi menjadi salah satu dasar untuk membantu dalam menentukan epitet spesies dari genera Streptomyces sebagai data pelengkap walaupun dasar identifikasi telah dilakukan secara molekuler.

Karakterisasi yang baik mengenai morfologi koloni pada medium yang berbeda sangat dibutuhkan dalam proses identifikasi dan penapisan potensi Streptomyces terkait fungsinya sebagai organisme penghasil senyawa antimikoba. International Streptomyces Project (ISP) merupakan standar karakterisasi dan digunakan oleh berbagai peneliti dalam mendeskripsikan karakter morfologi koloni dari kelompok Streptomyces pada media yang berbeda untuk mendukung proses identifikasi (Kim et al., 2003; Oskay 2009). Karakterisasi morfologi koloni pada medium agar dilakukan untuk mendeteksi dan mendeskripsikan Streptomyces secara tepat. Karakter utama yang diamati menurut panduan Holt et al. (2004) dan diadaptasi oleh penelitian Astuty (2017) adalah visualisasi miselia substrat, pola dan warna spora matang, miselia udara, dan pigmen terlarut pada media.

Nurkanto dan Agusta (2015) juga menyatakan bahwa karakterisasi morfologi merupakan faktor pendukung dan data penting dalam melakukan karakterisasi dan identifikasi. Melalui observasi data morfologi dan fisiologi dalam tahap identifikasi Streptomyces dapat digunakan untuk membantu dalam mendiskripsikan isolat-isolat yang sudah diidentifikasi secara molekuler. Hal ini dikarenakan sering dijumpai kemiripan jenis dari Streptomyces secara molekuler, namun berbeda secara morfologinya. Kasus ini ditemukan ketika proses identifikasi molekuler hanya dilakukan dengan satu atau beberapa gen penanda saja (Madigan et al. 2003). Datadata karakter morfologi, baik morfologi koloni pada media agar maupun morfologi sel, fisiologi sel melalui data pengujian biokimia, dan molekuler yang lengkap akan memberikan hasil yang akurat tentang identitas Streptomyces.

Oleh karena itu, tujuan dari penelitian ini adalah untuk melihat karakter morfologi koloni Streptomyces spp. guna memperkuat dasar identifikasi spesies dari variasi koloninya pada medium dasar yang berbeda. Hal ini menjadi preservasi data awal untuk melengkapi identifikasi selanjutnya secara fisiologi maupun molekuler sebagai penunjang pemanfaatan potensi Streptomyces spp. yang diisolasi dari substrat habitat cacing nipah.

\section{METODOLOGI}

\section{Preparasi Medium Streptomyces spp.}

Medium diferensial berupa Agar Kasein dan Amilum (CSA) (amilum terlarut 10 gram; kasein 0.3 gram; kalium nitrat 2 gram; dipotasium hidrogen fosfat 2 gram; natrium klorida 10 gram; kalsium karbonat 0.02 gram; besi sulfat 0.01 gram; agar 20 gram /L), Agar Ekstrak Khamir dan Malt (YMA) (pepton 5 gram; ekstrak khamir 3 gram; ekstrak malt 3 gram; dekstrosa 10 gram; agar 15 gram / 1000 ml akuades), Agar Amilum dan Garam Anorganik (ISSA) (amilum terlarut 10 gram; dipotasium hidrogen fosfat 1 gram; magnesium sulfat 1 gram; natrium klorida 1 gram; amonium sulfat 2 gram; kalsium karbonat 2 gram; besi (3) sulfat 0.001 gram; mangan klorida 0.001 gram; zinc (2) sulfat 0.001 gram; dan agar $20 \mathrm{gram} / 1000 \mathrm{ml}$ akuaes), Agar Oat (OA) (oat grain 30 gram, dan agar 15 gram/ $1000 \mathrm{ml}$ akuades) dan Agar Asparagin Gliserol (GAA) (L-asparagin 1 gram; dipotasium hidrogen fosfat 1 gram; FeSO4 0.001 gram; mangan klorida 0.001 gram; zinc (2) sulfat 0.001 gram; agar 20 gram/ $1000 \mathrm{ml}$ akuades) dihomogenisasi dengan akuades di atas hot-stir-plate pada suhu $100^{\circ} \mathrm{C}$ hingga mendidih. Semua medium agar kemudian disterilisasi 
menggunakan autoklaf dengan durasi 15 menit bersuhu $121^{\circ} \mathrm{C}$ dan tekanan udara 0.1 Mpa.

\section{Inokulasi Isolat Streptomyces spp. pada Medium Agar}

Isolat Streptomyces spp. diinokulasikan pada medium Agar Kasein dan Amilum (CSA), Agar Ekstrak Khamir dan Malt (YMA), Agar Amilum dan Garam Anorganik (ISSA), Agar Oat (OA), dan Agar Asparagin Gliserol (GAA) dengan metode goresan kuadran. Cawan agar inokulum diinkubasi pada suhu $31^{\circ} \mathrm{C}$ dan diamati pada hari ke tujuh dan empat belas setelah inkubasi.

\section{Karakterisasi Koloni Streptomyces spp. pada Medium Agar Diferensial}

Semua isolat bakteri dikultur pada Agar Kasein dan Amilum (CSA), Agar Ekstrak Khamir dan Malt (YMA), Agar Amilum dan Garam Anorganik (ISSA), Agar Oat (OA), dan Agar Asparagin Gliserol (GAA). Pertumbuhan koloni bakteri diamati untuk karakter morfologi meliputi bentuk, warna spora matang, warna koloni bawah atau hifa substrat, tekstur permukaan koloni, ada tidaknya miselium udara dan miselium substrat, dan pembentukan pigmen dan eksudat atau sekret pada permukaan atas koloni. Karakterisasi dilakukan pada inkubasi hari ketujuh dan keempat belas. Pengamatan karakter morfologi koloni dilakukan dengan metode pengamatan langsung dengan bantuan mikroskop binokuler.

\section{HASIL DAN PEMBAHASAN}

Pengamatan karakter morfologi koloni dari Streptomyces spp. pada medium Agar Kasein dan Amilum (CSA), Agar Ekstrak Khamir dan Malt (YMA), Agar Amilum dan Garam Anorganik (ISSA), Agar Oat (OA), dan Agar Asparagin Gliserol (GAA) memperlihatkan persamaan dan perbedaan karakter dari setiap isolat. Persamaan karakter terlihat pada karakter warna hifa substrat dan tekstur koloni. Meskipun warna hifa udara yang dipengaruhi oleh spora sebagian besar sama, namun pada isolat NrASA memiliki diffusible pigment dan eksudat atau sekret pada koloninya (Tabel 1).

Isolat-isolat Streptomyces spp. yang diisolasi dari substrat cacing nipah memiliki karakter warna hifa udara dan tekstur yang sesuai dengan karakter genus Streptomyces. Holt (2004) menyatakan bahwa genus ini memiliki sebagian besar warna spora hifa udara coklat muda hingga tua dan memiliki tekstur powdery atau seperti tepung dengan arah ke atas. Pengamatan inkubasi hari ke-14 dari semua isolat memperlihatkan tekstur bertepung atau powdery dibandingkan dengan inkubasi hari ke-7. Hal ini dikarenakan hampir semua hifa udara menghasilkan spora pada hari ke-14 sehingga pengamatan di hari tersebut terlihat lebih memperlihatkan tekstur bertepung atau powdery dibandingkan hari ke-7.

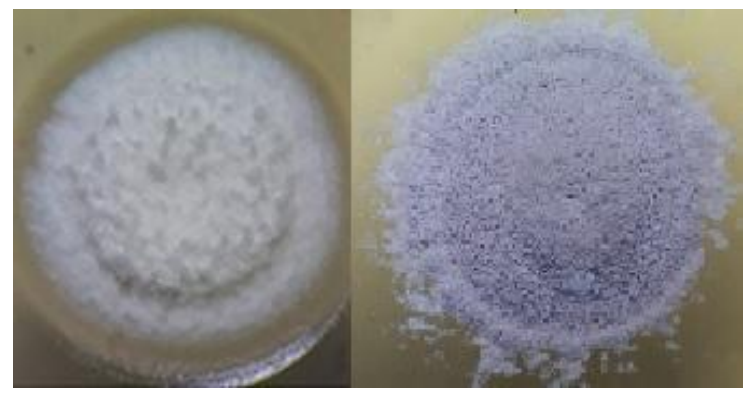

Gambar 1: Perubahan Tekstur Streptomyces dari seperti Kapas atauCottony pada Hari ke-7 (kiri) menjadi Bertepung atau Powdery pada Hari ke-14 (kanan).

Tekstur bertepung atau powdery pada tekstur koloni Streptomyces isolat substrat cacing nipah dibentuk dari kumpulan spora pada ujung hifa udara yang menumpuk dan menutupi hifa sehingga terlihat seperti adanya butiran tepung di atas permukaan koloni (Gambar 1).

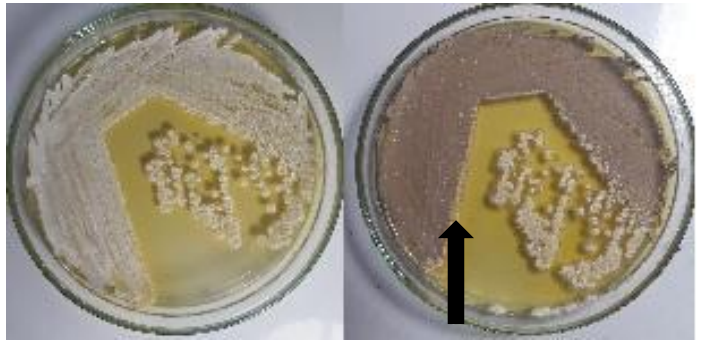


Gambar 2: Perubahan Warna Koloni Streptomyces pada Hari ke-7 (kiri) dan ke-14 (kanan). Warna

Coklat Permukaan Koloni Menandakan Spora Matur. Tanda Panah Memperlihatkan Perubahan Warna Dasar Medium (kuning) Akibat Sekresi Pigmen Terlarut.

Hasil pengamatan yang dilakukan Akbar et al. (2017) terhadap koloni Streptomyces sp. yang diisolasi dari perakaran tanaman mangrove Segara Anakan Cilacap juga memperlihatkan bentuk dan tekstur permukaa yang powdery atau seperti tepung dengan warna krem kecoklatan yang mengarah $\mathrm{ke}$ atas. Hasil ini memiliki kesesuaian dengan deskripsi dari panduan Holt et al. (2004) bahwa ciri khas Streptomyces adalah koloninya ditutup dengan miselia udara yang ditutupi spora matang di ujung hifanya. Ensign dan Barnard (2002) dalam artikel Kawuri (2016) juga menyatakan bahwa tekstur permukaan koloni bertepung atau powdery merupakan hifa dewasa yang mengalami proses maturasi sporanya.

Ada tidaknya sekresi eksudat dan pigmen terlarut pada permukaan agar dapat menentukan jenis dan karakter dari Streptomyces. Dari enam isolat yang diuji, satu isolat Streptomyces cacing nipah hasil karakterisasi pigmen terlarut dan sekret eksudat sama sekali tidak memproduksi sekret eksudat dan pigmen terlarut pada semua media diferensial, yakni Streptomyces kode NrASA5. Keempat isolat lainnya terlihat adanya pigmen terlarut dan sekret eksudat atau salah satu dari keduanya walaupun tidak diproduksi pada semua medium diferensial (Tabel 1).

Hanya satu isolat Streptomyces yang dapat memproduksi pigmen terlarut dan sekret eksudat pada koloni dan yang berdifusi pada permukaan medium diferensial, yakni Streptomyces sp. Kode NrASA1. Tiga isolat lainnya, yakni Streptomyces sp. kode NrASA2, NrASA3, NrASA4 dan NrASA6 terlihat tidak memproduksi keduanya (Tabel 1.).
Isolat NrASA2 hanya memproduksi sekret eksudat saja pada medium SCA dan ISSA tanpa memproduksi pigmen kuning, sehingga menyebabkan tidak terlihat perubahan perubahan warna medium di sekitar permukaan agar (Gambar 3). Isolat NrASA3 hanya memproduksi pigmen terlarut berwarna kuning pada medium SCA, OA, YMA, dan GAA. Isolat NrASA4 hanya memproduksi pigmen terlarut berwarna kuning pada medium OA dan GAA saja, sedangkan pigmen terlarut berwarna kuning pada isolat NrASA6 hanya terlihat pada medium SCA dan GAA (Gambar 2).

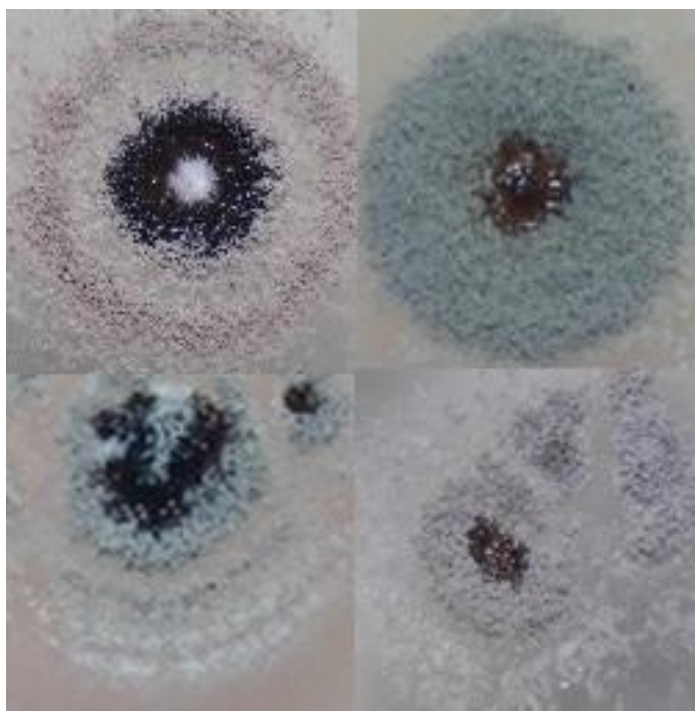

Gambar 3: Eksudat Coklat Tua di Permukaan Udara Koloni Streptomyces Isolat NrASA1 (baris atas) dan NrASA2 (baris bawah).

Eksudat dan sekret berwarna coklat kehitaman muncul pada Streptomyces isolat NrASA 1 dan NrASA2. Meskipun pada NrASA1 terdeteksi diffusible pigment atau pigmen terlarut pada permukaan medium SCA dan GAA, sekret coklat kehitaman juga ditemukan pada medium ISSA yang tidak mensekresikan pigmen terlarut pada permukaan agarnya. Sekret berwarna coklat kehitaman pada permukaan udara diduga merupakan sekret protein yang dihasilkan oleh hifa udara. 
Tabel 1: Karakter Streptomyces spp pada Medium Agar Berbeda.

\begin{tabular}{|c|c|c|c|c|c|}
\hline \multirow{2}{*}{$\begin{array}{l}\text { Kode } \\
\text { isolat }\end{array}$} & \multirow[b]{2}{*}{ Medium } & \multicolumn{4}{|c|}{ Karakter Koloni } \\
\hline & & Warna miselia udara & $\begin{array}{l}\text { Warna miselia } \\
\text { substrat }\end{array}$ & Tekstur & Presensi pigmen \\
\hline \multirow[t]{5}{*}{ NrASA1 } & SCA & $\begin{array}{l}\text { Putih dan } \text { coklat }^{(\mathrm{H} 7)} \\
\text { coklat tua }^{(\mathrm{H} 14)}\end{array}$ & Putih $^{(\mathrm{H} 7)} ;$ putih $^{(\mathrm{H} 14)}$ & $\begin{array}{l}\text { Seperti } \operatorname{kapas}^{(\mathrm{H} 7)} \text {; } \\
\text { bertepung }\end{array}$ & $\begin{array}{l}\text { Ada (kuning tua) }{ }^{(\mathrm{H} 7)} \text {; } \\
\text { eksudat coklat }^{(\mathrm{H} 14)}\end{array}$ \\
\hline & ISSA & $\begin{array}{l}\text { Putih dan } \text { coklat }^{(\mathrm{H} 7)} \text {; } \\
\text { coklat }^{(\mathrm{H} 14)}\end{array}$ & Putih $^{(\mathrm{H} 7)} ;$ putih $^{(\mathrm{H14})}$ & $\begin{array}{l}\text { Seperti } \text { kapas }^{(\mathrm{H} 7)} \text {; } \\
\text { bertepung }\end{array}$ & $\begin{array}{l}\text { Tidak ada }{ }^{(\mathrm{H} 7)} \text {; eksudat } \\
\text { coklat }^{(\mathrm{H} 14)}\end{array}$ \\
\hline & OA & $\begin{array}{l}\text { Putih dan } \text { coklat }^{(\mathrm{H7})} \\
\text { coklat }^{(\mathrm{H} 14)}\end{array}$ & $\mathrm{Putih}^{(\mathrm{H7})} ;$ putih $^{(\mathrm{H} 14)}$ & $\begin{array}{l}\text { Seperti } \text { kapas }^{(\mathrm{H} 7)} \text {; } \\
\text { bertepung }\end{array}$ & $\begin{array}{l}\text { Ada (kuning tua) }{ }^{(\mathrm{H} 7)} \text {; } \\
\text { kuning tua }^{(\mathrm{H} 14)}\end{array}$ \\
\hline & YMA & $\begin{array}{l}\text { Putih dan } \text { coklat }^{(\mathrm{H} 7)} \\
\text { coklat }^{(\mathrm{H} 14)}\end{array}$ & Putih $^{(\mathrm{H} 7)} ;$ putih $^{(\mathrm{H} 14)}$ & $\begin{array}{l}\text { Seperti } \text { kapas }^{(\mathrm{H} 7)} \text {; } \\
\text { bertepung }\end{array}$ & $\begin{array}{l}\text { Ada (kuning tua) }{ }^{(\mathrm{H} 7)} \text {; } \\
\text { eksudat coklat }{ }^{(\mathrm{H} 14)}\end{array}$ \\
\hline & GAA & Putih $^{(\mathrm{H} 7)} ;$ Coklat $^{(\mathrm{H} 14)}$ & Putih $^{(\mathrm{H} 7)} ;$ putih $^{(\mathrm{H} 14)}$ & $\begin{array}{l}\text { Seperti } \text { kapas }^{(\mathrm{H} 7)} \text {; } \\
\text { bertepung }\end{array}$ & $\begin{array}{l}\text { Ada (kuning tua) }{ }^{(\mathrm{H} 7)} \text {; } \\
\text { kuning tua }^{(\mathrm{H} 14)}\end{array}$ \\
\hline \multirow[t]{5}{*}{ NrASA2 } & SCA & $\begin{array}{l}\text { Putih dan } \text { coklat }^{(\mathrm{H} 7)} \text {; } \\
\text { coklat tua }^{(\mathrm{H} 14)}\end{array}$ & Putih $^{(\mathrm{H} 7)} ;$ putih $^{(\mathrm{H} 14)}$ & $\begin{array}{l}\text { Seperti } \text { kapas }^{(\mathrm{H} 7)} \text {; } \\
\text { bertepung }\end{array}$ & Eksudat coklat tua \\
\hline & ISSA & $\begin{array}{l}\text { Putih dan } \text { coklat }^{(\mathrm{H} 7)} \\
\text { coklat tua }^{(\mathrm{H} 14)}\end{array}$ & Putih $^{(\mathrm{H7})} ;$ putih $^{(\mathrm{H} 14)}$ & $\begin{array}{l}\text { Seperti } \text { kapas }^{(\mathrm{H} 7)} \text {; } \\
\text { bertepung }{ }^{(\mathrm{H} 14)}\end{array}$ & Eksudat coklat \\
\hline & $\mathrm{OA}$ & $\begin{array}{l}\text { Putih dan } \operatorname{coklat}^{(\mathrm{H} 7)} \\
\text { coklat tua }^{(\mathrm{H} 14)}\end{array}$ & Putih $^{(\mathrm{H7})} ;$ putih $^{(\mathrm{H} 14)}$ & $\begin{array}{l}\text { Seperti } \text { kapas }^{(\mathrm{H} 7)} \text {; } \\
\text { bertepung }\end{array}$ & Tidak ada \\
\hline & YMA & Putih $^{(\mathrm{H} 7)} ;$ Coklat $^{(\mathrm{H} 14)}$ & Putih $^{(\mathrm{H} 7)} ;$ putih $^{(\mathrm{H} 14)}$ & $\begin{array}{l}\text { Seperti } \text { kapas }^{(\mathrm{H} 7)} \text {; } \\
\text { bertepung }\end{array}$ & Tidak ada \\
\hline & GAA & $\begin{array}{l}\text { Putih dan coklat } \\
\text { muda }^{(\mathrm{H7})} ; \text { coklat tua }^{(\mathrm{H} 14)}\end{array}$ & $\mathrm{Putih}^{(\mathrm{H} 7)} ; \operatorname{putih}^{(\mathrm{H} 14)}$ & $\begin{array}{l}\text { Seperti } \text { kapas }^{(\mathrm{H} 7)} \text {; } \\
\text { bertepung }\end{array}$ & Tidak ada \\
\hline \multirow[t]{5}{*}{ NrASA3 } & SCA & $\begin{array}{l}\text { Putih dan coklat } \\
\text { muda }^{(\mathrm{H} 7)} ; \text { coklat tua }^{(\mathrm{H} 14)}\end{array}$ & $\mathrm{Putih}^{(\mathrm{H} 7)} ;$ putih $^{(\mathrm{H} 14)}$ & $\begin{array}{l}\text { Seperti } \text { kapas }^{(\mathrm{H} 7)} \text {; } \\
\text { bertepung }\end{array}$ & $\begin{array}{l}\text { Ada }{\text { (kuning })^{(\mathrm{H} 7)} \text {; }}_{\text {kuning }^{(\mathrm{H} 14)}}\end{array}$ \\
\hline & ISSA & $\begin{array}{l}\text { Putih dan coklat } \\
\text { muda }^{(\mathrm{H7})} ; \text { coklat }^{(\mathrm{H} 14)}\end{array}$ & $\mathrm{Putih}^{(\mathrm{H} 7)} ;$ putih $^{(\mathrm{H} 14)}$ & $\begin{array}{l}\text { Seperti } \text { kapas }^{(\mathrm{H} 7)} \text {; } \\
\text { bertepung }\end{array}$ & Tidak ada \\
\hline & $\mathrm{OA}$ & $\begin{array}{l}\text { Putih dan coklat } \\
\text { muda }^{(\mathrm{H7})} ; \text { coklat tua }^{(\mathrm{H} 14)}\end{array}$ & Putih $^{(\mathrm{H} 7)} ; \operatorname{putih}^{(\mathrm{H} 14)}$ & $\begin{array}{l}\text { Seperti } \text { kapas }^{(\mathrm{H} 7)} \text {; } \\
\text { bertepung }\end{array}$ & $\begin{array}{l}\text { Ada }{\text { (kuning })^{(\mathrm{H} 7)} \text {; }}_{\text {kuning }^{(\mathrm{H} 14)}}\end{array}$ \\
\hline & YMA & $\begin{array}{l}\text { Putih dan coklat } \\
\text { muda }^{(\mathrm{H7})} ; \text { coklat tua }^{(\mathrm{H14})}\end{array}$ & $\operatorname{Putih}^{(\mathrm{H} 7)} ; \operatorname{putih}^{(\mathrm{H} 14)}$ & $\begin{array}{l}\text { Seperti } \text { kapas }^{(\mathrm{H} 7)} \text {; } \\
\text { bertepung }\end{array}$ & $\begin{array}{l}\text { Ada }{\text { (kuning })^{(\mathrm{H} 7)} \text {; }}_{\text {kuning }^{(\mathrm{H} 14)}}\end{array}$ \\
\hline & GAA & $\begin{array}{l}\text { Coklat muda }{ }^{(\mathrm{H7})} ; \text { coklat } \\
\text { tua }^{(\mathrm{H} 14)}\end{array}$ & Putih $^{(\mathrm{H} 7)} ;$ putih $^{(\mathrm{H14})}$ & $\begin{array}{l}\text { Seperti } \text { kapas }^{(\mathrm{H} 7)} \text {; } \\
\text { bertepung }\end{array}$ & 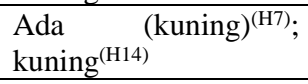 \\
\hline \multirow[t]{5}{*}{ NrASA4 } & SCA & $\begin{array}{l}\text { Putih dan coklat } \\
\text { muda }^{(\mathrm{H} 7)} ; \text { coklat tua }^{(\mathrm{H} 14)}\end{array}$ & $\mathrm{Putih}^{(\mathrm{H7})} ;$ putih $^{(\mathrm{H} 14)}$ & $\begin{array}{l}\text { Seperti } \text { kapas }^{(\mathrm{H} 7)} \text {; } \\
\text { bertepung }\end{array}$ & Tidak ada \\
\hline & ISSA & $\begin{array}{l}\text { Putih dan coklat } \\
\text { muda }^{(\mathrm{H})} ; \text { putih dan } \\
\text { coklat tua }^{(\mathrm{H} 14)}\end{array}$ & Putih $^{(\mathrm{H} 7)} ;$ putih $^{(\mathrm{H} 14)}$ & $\begin{array}{l}\text { Seperti } \text { kapas }^{(\mathrm{H} 7)} \text {; } \\
\text { bertepung }\end{array}$ & Tidak ada \\
\hline & $\mathrm{OA}$ & $\begin{array}{l}\text { Putih dan coklat } \\
\text { muda }^{(\mathrm{H} 7)} ; \text { putih dan } \\
\text { coklat tua }^{(\mathrm{H} 14)}\end{array}$ & Putih $^{(\mathrm{H} 7)} ; \operatorname{putih}^{(\mathrm{H} 14)}$ & $\begin{array}{l}\text { Seperti } \text { kapas }^{(\mathrm{H} 7)} \text {; } \\
\text { bertepung }\end{array}$ & $\begin{array}{l}\text { Ada }{\text { (kuning })^{(\mathrm{H} 7)} \text {; }}_{\text {kuning }^{(\mathrm{H} 14)}}\end{array}$ \\
\hline & YMA & $\begin{array}{l}\text { Putih dan coklat } \\
\text { muda }^{(\mathrm{H})} ; \text { putih dan } \\
\text { coklat tua }^{(\mathrm{H} 14)}\end{array}$ & Putih $^{(\mathrm{H} 7)} ;$ putih $^{(\mathrm{H14})}$ & $\begin{array}{l}\text { Seperti } \text { kapas }^{(\mathrm{H} 7)} \text {; } \\
\text { bertepung }\end{array}$ & Tidak ada \\
\hline & GAA & $\begin{array}{l}\text { Coklat muda }{ }^{(\mathrm{H7})} ; \text { coklat } \\
\text { tua }^{(\mathrm{H} 14)}\end{array}$ & Putih $^{(\mathrm{H} 7)} ;$ putih $^{(\mathrm{H} 14)}$ & $\begin{array}{l}\text { Seperti } \text { kapas }^{(\mathrm{H} 7)} \text {; } \\
\text { bertepung }\end{array}$ & $\begin{array}{l}\text { Ada }{\text { (kuning })^{(\mathrm{H} 7)} \text {; }}_{\text {kuning }^{(\mathrm{H} 14)}}\end{array}$ \\
\hline \multirow[t]{5}{*}{ NrASA5 } & SCA & $\begin{array}{l}\text { Putih }^{(\mathrm{H} 7)} ; \\
\text { muda }^{(\mathrm{H} 14)}\end{array}$ & Putih $^{(\mathrm{H} 7)} ;$ putih $^{(\mathrm{H} 14)}$ & $\begin{array}{l}\text { Seperti } \text { kapas }^{(\mathrm{H} 7)} \text {; } \\
\text { bertepung }\end{array}$ & Tidak ada \\
\hline & ISSA & $\begin{array}{l}\text { Putih }^{(\mathrm{H} 7)} ; \quad \text { abu-abu } \\
\text { bagian center }^{(\mathrm{H14})}\end{array}$ & Putih $^{(\mathrm{H} 7)} ; \operatorname{putih}^{(\mathrm{H} 14)}$ & $\begin{array}{l}\text { Seperti } \text { kapas }^{(\mathrm{H} 7)} \text {; } \\
\text { bertepung }\end{array}$ & Tidak ada \\
\hline & OA & $\begin{array}{l}\text { Putih }^{(\mathrm{H} 7)} ; \quad \text { abu-abu } \\
\text { bagian center }^{(\mathrm{H} 14)}\end{array}$ & Putih $^{(\mathrm{H} 7)} ;$ putih $^{(\mathrm{H} 14)}$ & $\begin{array}{l}\text { Seperti } \text { kapas }^{(\mathrm{H} 7)} \text {; } \\
\text { bertepung }\end{array}$ & Tidak ada \\
\hline & YMA & $\begin{array}{l}\text { Putih }^{(\mathrm{H} 7)} ; \quad \text { abu-abu } \\
\text { bagian center }^{(\mathrm{H} 14)}\end{array}$ & $\mathrm{Putih}^{(\mathrm{H7})} ;$ putih $^{(\mathrm{H} 14)}$ & $\begin{array}{l}\text { Seperti } \text { kapas }^{(\mathrm{H} 7)} \text {; } \\
\text { bertepung }{ }^{(\mathrm{H} 14)}\end{array}$ & Tidak ada \\
\hline & GAA & $\begin{array}{l}\text { Putih }^{(\mathrm{H} 7)} ; \quad \text { abu-abu } \\
\text { bagian center }^{(\mathrm{H} 14)}\end{array}$ & Putih $^{(\mathrm{H7})} ;$ putih $^{(\mathrm{H} 14)}$ & $\begin{array}{l}\text { Seperti } \text { kapas }^{(\mathrm{H} 7)} \text {; } \\
\text { bertepung }\end{array}$ & Tidak ada \\
\hline \multirow[t]{3}{*}{ NrASA6 } & SCA & Putih $^{(\mathrm{H} 7)} ;$ putih $^{\mathrm{H} 14)}$ & Putih $^{(\mathrm{H} 7)} ;$ putih $^{(\mathrm{H} 14}$ & $\begin{array}{l}\text { Seperti } \text { kapas }^{(\mathrm{H} 7)} \text {; } \\
\text { bertepung }\end{array}$ & $\begin{array}{l}\text { Ada }{\text { (kuning })^{(\mathrm{H} 7)} \text {; }}_{\text {kuning }^{(\mathrm{H} 14)}}\end{array}$ \\
\hline & ISSA & $\begin{array}{l}\text { Putih }^{(\mathrm{H} 7)} ; \text { coklat bagian } \\
\text { center } \mathrm{r}^{(\mathrm{H} 14)}\end{array}$ & Putih $^{(\mathrm{H} 7)} ;$ putih $^{(\mathrm{H} 14}$ & $\begin{array}{l}\text { Seperti } \text { kapas }^{(\mathrm{H} 7)} \text {; } \\
\text { bertepung }\end{array}$ & Tidak ada \\
\hline & $\mathrm{OA}$ & $\begin{array}{l}\text { Putih }{ }^{(\mathrm{H} 7)} ; \text { cokat bagian } \\
\text { center }^{(\mathrm{H} 14)}\end{array}$ & Putih $^{(\mathrm{H7})} ;$ putih $^{(\mathrm{H} 14}$ & $\begin{array}{l}\text { Seperti } \text { kapas }^{(\mathrm{H} 7)} \text {; } \\
\text { bertepung }\end{array}$ & Tidak ada \\
\hline
\end{tabular}




\begin{tabular}{|c|c|c|c|c|c|}
\hline \multirow{3}{*}{$\begin{array}{l}\text { Kode } \\
\text { isolat }\end{array}$} & \multirow{3}{*}{$\begin{array}{l}\text { Medium } \\
\text { YMA }\end{array}$} & \multicolumn{4}{|c|}{ Karakter Koloni } \\
\hline & & Warna miselia udara & $\begin{array}{l}\text { Warna miselia } \\
\text { substrat }\end{array}$ & Tekstur & Presensi pigmen \\
\hline & & $\begin{array}{l}\text { Coklat } \text { muda }^{(\mathrm{H} 7)} \text {; coklat } \\
\text { tua }^{(\mathrm{H} 14)}\end{array}$ & Putih $^{(\mathrm{H} 7)} ;$ putih $^{(\mathrm{H} 14}$ & $\begin{array}{l}\text { Seperti } \text { kapas }^{(\mathrm{H} 7)} \text {; } \\
\text { bertepung }{ }^{(\mathrm{H} 14)}\end{array}$ & Tidak ada \\
\hline & GAA & $\begin{array}{l}\text { Coklat muda }{ }^{(\mathrm{H} 7)} ; \text { coklat } \\
\text { tua }\end{array}$ & Putih $^{(\mathrm{H} 7)} ;$ putih $^{(\mathrm{H} 14}$ & $\begin{array}{l}\text { Seperti } \text { kapas }^{(\mathrm{H7})} \text {; } \\
\text { bertepung }{ }^{(\mathrm{H} 14)}\end{array}$ & $\begin{array}{l}\text { Ada (kuning) })^{(\mathrm{H} 7)} \text {; } \\
\text { kuning }^{(\mathrm{H} 14)}\end{array}$ \\
\hline
\end{tabular}

Keterangan: H-7: Pengamatan hari ketujuh; H-14: Pengamatan hari ke empat belas

Tidak konsistennya kemunculan pigmen terlarut pada medium diferensial yang berbeda seperti pada Streptomyces dengan kode isolat NrASA1, NrASA4 dan NrASA6 dikarenakan perbedaan komposisi kimia medium yang ada (Gambar 4). Pernyataan Sutedjo et al. (1991) dalam artikel Kawuri (2016) menyatakan bahwa Streptomyces akan menghasilkan pigmen dan intensitas yang berbeda-beda tergantung pada jenis medium. Hal ini berkaitan dengan pengaruh kandungan nutrisi pada media yang tidak sama.

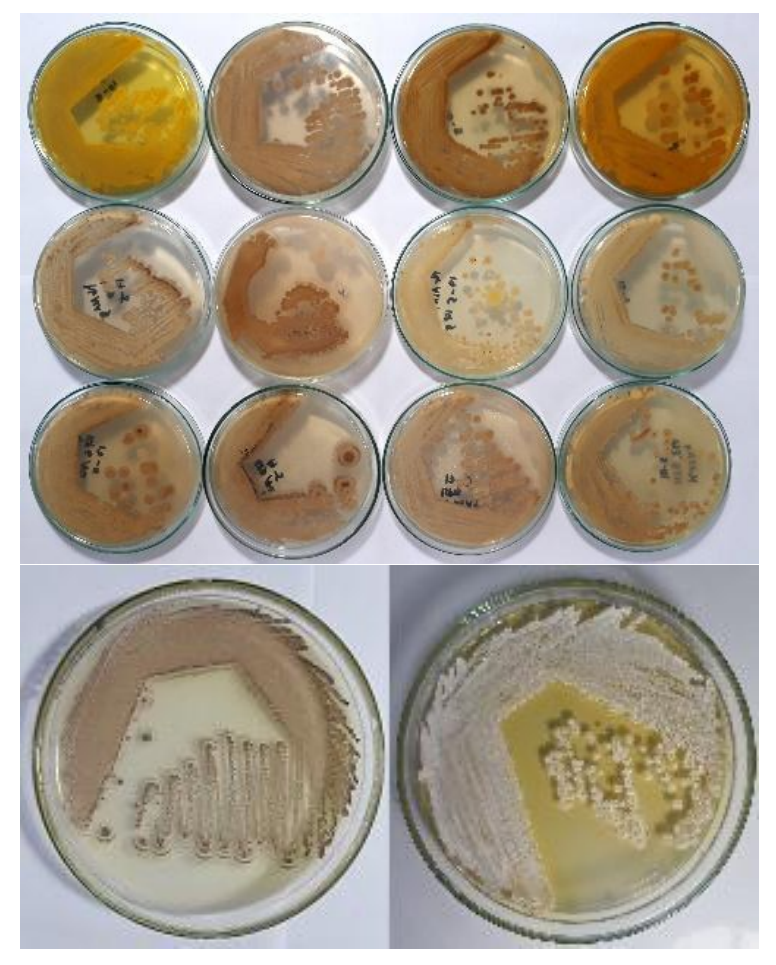

Gambar 4: Pigmen Kuning pada Permukaan Agar Ditandai Adanya Perubahan Warna pada Medium Diferensial Agar (atas). Streptomyces Kode Nrasa1 pada Medium ISSA Tanpa Produksi Pigmen (kiri) dan pada Medium CSA dengan Produksi Pigmen Kuning (kanan) pada Inkubasi Lima Hari.

Produksi pigmen pada medium padat oleh Streptomyces dipengaruhi oleh $\mathrm{pH}$, karbon, dan sumber nitrogen di medium. Jenis, konsentrasi sumber karbon dan nitrogen serta komposisi mineral media kultur berdampak pada sintesis metabolit pada Streptomyces (Vijayabharathi et al. 2011). Hasil penelitian Abraham dan Chauhan (2018) mengenai pemanfaatan pati, dan dekstrosa oleh Streptomyces untuk produksi senyawa metabolit bioaktif menunjukkan bahwa substrat tersebut bertindak sebagai sistem serapan aktif untuk Streptomyces sp. Hal ini juga telah telah dilaporkan sebelumnya oleh Dharamraj (2009) yang menyarankan pemberian cekaman atau tekanan selama rentang hidup yang kompleks, genus bakteri Streptomyces yang hidup di tanah dengan berbagai tekanan atau cekaman nutrisi dan lingkungan akan memberikan keuntungan dalam produksi metabolit sekunder sehingga produksi pigmen dapat meningkat dan memberikan keunggulan kompetitif di lingkungan dan dapat dimanfaatkan oleh peneliti untuk meningkatkan aktivitas hambatan terhadap mikrob patogen (Staric et al. 2010).

Medium Starch Casein Agar (SCA) dan Glycerol Asparagin Agar (GAA) lebih sering menyebabkan Streptomyces memproduksi pigmen dibandingkan dengan medium lainnya. Hal ini dikarenakan adanya perbedaan kecepatan pertumbuhan. Hasil pengamatan menunjukkan bahwa pertumbuhan Streptomyces pada SCA dan GAA lebih baik dibandingkan dengan medium lainnya. Hasil penelitian yang dilakukan oleh Muzaimah et al. (2017) juga memperlihatkan pola yang sama bahwa Streptomyces yang diisolasi dari rizosfer tanaman sawit lebih cenderung membentuk pigmen pada medium SCA dibandingkan dengan medium lainnya.

Hasil penelitian dan penulisan ini diharapkan menjadi dasar karakterisasi dan 
identifikasi Streptomyces berkelanjutan. Hal ini dilengkapi dengan karakterisasi sifat fisiologi atau biokimianya dan diperkuat dengan identifikasi secara molekuler melalui isolasi 16sRNAnya. Isolat Streptomyces spp. yang diisolasi dari habitat cacing nipah diharapkan memiiki potensi metabolit sebagai antimikroba yang membantu dalam penghambatan patogen bagi cacing nipah.

\section{KESIMPULAN}

Semua karakter Streptomyces spp. yang diisolasi dari substrat habitat cacing nipah pada medium yang berbeda memiliki konsistensi pada karakter warna hifa dan spora matang, hifa substrat, dan tekstur koloni. Namun tidak pada karakter produksi pigmen dan eksudat pada permukaan koloni, dimana hanya tiga isolat yang dapat memproduksi pigmen dan sekret pada koloni dan yang berdifusi pada permukaan agar medium.

\section{UCAPAN TERIMA KASIH}

Ucapan terima kasih tin peneliti sampaikan kepada pimpinan Fakultas Matematika dan Ilmu Pengetahuan Alam Universitas Tanjungpura Pontianak atas dukungan finansial atas telaksananya penelitian dan penulisan artikel ini.

\section{DAFTAR PUSTAKA}

Abraham J, Chauhan R. (2018). Profiling of Red Pigment Produced by Streptomyces sp.. JAR6 and its Bioactivity. 3 Biotech. 8(1): 22

Akbar A R, Ryandini D, Kusharyati D F. (2017). Potensi Actinomycetes Asal Tanah Perakaran Mangrove Segara Anakan Cilacap sebagai Penghasil Antifungi terhadap Candida albicans. Journal of Tropical Biodiversity and Biotechnology. 2: 39 - 44

Astuty E. (2017). Isolasi dan Karakterisasi Morfologi Aktinomiset Indigenus
Asal Tanah Gambut, Jurnal Ilmu Alam dan Lingkungan, 8 (16):7 - 15

Dharamraj S. (2009). Study of Lasparaginase Production by Streptomyces noursei MTCC 10469 Isolated from Marine Sponge Callyspongia diffusa. Iran $J$ Biotechnol., 9:2-10

Ekowati C N, Achmad A. (2007). Pengaruh Kompos Kulit Buah Kopi (Coffea robusta Lind.) dan Kacang Pinto (Arachis pintoi Krapov dan Gregory) terhadap Keanekaragaman Actinomycetes. J. Sains MIPA. 13(3): $177-182$

Fardiyanti R, Kasrina, Bustaman H. (2021). Ragam Jenis Streptomyces sp. pada Rizosfer Tanaman Suku Liliacea di Kawasan Desa Sumber Bening, Rejang Lebong, Bengkulu. Konservasi Hayati. 17(1): 29-34

Kawuri R. (2016). Isolasi dan Identifikasi Streptomyces sp. pada Rhizosfer Tanaman Pisang (Musa paradiasica) di Desa Pendem Jembrana Bali. Jurnal Metamorfosa. 3(2): 140-148

Kim Y P, Tomoda H, Lizima K, Fukuda T, Matsumoto A, Takahashi Y, Omura S. (2003). Takanawaenes, Novel Antifungal Antibiotics Produced by Streptomyces sp. K99-5278. The Journal of Antibiotics. 56(5): 448-453

Madigan M T, Martinko J M, Parker J. (2009). Biology of Microorganisms. 12th edition. New York: Prentice Hall International.

Muzaimah S A, Idris S A, Madihah A Z, Kamaruzzaman S, Maizatul-Suiza M. (2017). Characterization of Streptomyces $\quad$ spp. Isolated from the Rhizosphere of Oil Palm and Evaluation of their Ability to Suppress Basal Stem Rot Disease in Oil Palm Seedlings when Applied as Powder Formulations in a Glasshouse Trial. World Journal 
of Microbiology and Biotechnology. (2018) 34:15

Nurkanto A, Agusta A. (2015). Identifikasi Molekular dan Karakterisasi Morfofisiologi Actinomycetes Penghasil Senyawa Antimikroba. Jurnal Biologi Indonesia. 11(2): 195-203

Oskay M. (2009). Comparison of Streptomyces Diversity between Agricultural and Non-Agricultural Soils by Using Various Culture Media. Scientific Research and Essay. 4(10): 997-1005

Sivalingam P, Hong K,Pote J, Prabakar K. (2019). Extreme Environment Streptomyces: Potential Sources for New Antibacterial and Anticancer Drug Leads?, Hindawi International Journal of Microbiology, 2019: 1-19

Staric N, Danevcic T, Stopar D. (2020). Vibrio sp. DSM 14379 pigment production-a competitive advantage in the environment. Micro Ecol.. 60:592-598
Vijayabharathi R, Bruheim P, Andreassen T, Raja DS, Devi PB, Satyabhama S, Priyadarshini VB. (2011). Assessment of Resistomycin, as an Anticancer Compound Isolated and Characterized from Streptomyces aurantiacus. J Microbiol. 49: 920926

Yanti A H, Setyawati T R, Kurniatuhadi R. (2020). Composition and Characteristics of Actinomycetes Isolated from Nipah Mangrove Sediment, Gastrointestinal and Fecal Pellets of Nipah Worm (Namalycastis rhodhocorde), IOP Conf. Ser.: Earth Environ. Sci. 550012003

Yepes-García J, Caicedo-Montoya C, Pinilla L, Toro L F, Ríos-Estepa R. (2020). Morphological Differentiation of Streptomyces clavuligerus Exposed to Diverse Environmental Conditions and its Relationship with Clavulanic Acid Biosynthesis. Processes. 8: 2-17

Holt. J G. (2004). Bergey's Manual Determinative Bacteriology. Baltimore: Williamn and Wilkins Baltimore. 